\title{
PENINGKATKAN MOTIVASI BELAJAR SISWA MELALUI KETERAMPILAN BERKOMUNIKASI GURU
}

\author{
Moh. Turmudi*
}

\begin{abstract}
Abstrak
Komunikasi memegang peranan penting dalam proses pembelajaran di kelas, karena pada hakekatnya bahwa mengajar itu adalah berkomunikasi itu sendiri. Untuk menjadi guru yang sukses dalam pembelajarannya, ia harus menguasai strategi berkomunikasi, yaitu kemampuan membaca emosi siswanya dan sekaligus mengelola emosinya untuk dipengaruhi dalam konteks pembelajaran. Untuk meningkatkan kemampuan berkomunikasi dalam proses pembelajaran, seorang guru harus memiliki keterampilan dasar mengajar yang memadahi, perlu instrospeksi diri, terbuka terhadap kritik dan inovasi, dan memiliki kecerdasan emosional yang baik.
\end{abstract}

Kata Kunci: Motivasi Belajar, Komunikasi Guru

\section{Pendahuluan}

Pembicaraan mengenal mutu pendidikan di Indonesia dewasa ini tetap menjadi wacana yang menarik perhatian berbagai kalangan, tidak hanya kalangan pendidik dan profesional, tetapi juga bagi masyarakat yang menginginkan muculnya perubahan dalam hal usaha meningkatkan mutu pendidikan. ${ }^{1}$ Berbagai upaya telah dan akan ditempuh oleh pemerintah dalam hal ini, kementrian Pendidikan dan Kebudayaan Nasional untuk meningkatkan mutu pendidikan. Usaha-usaha pengembangan kompetensi guru dilakukan melalui penataran-penataran mengenai kurikulum, prosedur pengembangan sistem intruksional, Musyawarah Guru bidang

\footnotetext{
* Institut Agama Islam Tribakti (IAIT) Kediri

H.A.R.Tilaar, Manajemen Pendidikan Nasional: Kajian Pendidikan Masa Depan, (Bandung: Remaja Rosdakarya, 1998), h. 5
} 
studi merupakan sebagian dari usaha pemerintah dalam rangka meningkatkan mutu pendidikan, khususnya mutu guru. Yang akhirnya juga bermuara pada peningkatan mutu siswa mendatang.

Guru dan siswa seharusnya mendapat perhatian yang serius, sebab guru merupakan faktor yang paling penting dalam pendidikan. Perlunya perhatian yang besar ini didasari oleh kenyataan bahwa keberhasilan pendidikan sangat ditentukan oleh faktor guru. Dalam konteks ini tidak bermaksud memperkecil peran-peran yang lain yang terlibat langsung maupun tidak langsung dalam sistem pendidikan di sekolah.

Guru yang memahami kedudukan dan fungsinya sebagai pendidik professional selalu terdorong untuk tumbuh dan berkembang dalam jabatannya. Oleh karena itu kreatifitas dan inisiatif dari guru harus didorong dan dimanfaatkan secara kongkrit agar ia memperoleh pengalaman profesional di bidang pendidikan. Guru yang terus menerus tumbuh dan berkembang secara profesional akan mampu menciptakan situasi belajar mengajar yang dinamis di kelas maupun di luar kelas.

Kebutuhan pengembangan profesi guru merupakan hal yang prinsipil, apalagi kalau diamati bahwa pendidikan bukanlah hal yang statis, tetapi selalu dinamis. Pendidikan selalu berkembang seiring dengan perkembangan ilmu pengetahuan dan teknologi serta kemajuan sosial lainnya.

"The unsatisfactory result of the teaching English is caused by many factors related to the linguistic and non-linguistic areas, some factors that can be attributed to unsatisfactory condition are, the language system which is different from Indonesian, the teacher, the learners, the curriculum and materials, and the attitude of society toward the English teaching." 2

Dari pendapat di atas dapat disimpulkan bahwa salah satu ketidak-berhasilan pembelajaran adalah terletak pihak guru dan siswa itu sendiri. Oleh karena itu penulis berusaha untuk mengangkat permasalahan dengan menghubungkan dua variabel siswa dan guru. Dari kedua belah pihak tersebut, dari sisi siswa

${ }^{2}$ Hardin, Carlette Jackson. Effective Classroom Management; model and strategies for today's classroom. (New Jersey: Pearson Education, Inc. 2004), h. 32 
bagaimana meningkatkan motivasi siswa dalam belajarmengajar dan bagaimana usaha guru untuk meningkatkan motivasi belajar siswa dengan keterampilan komunikasi sebagai salah satu komponen manajemen kelas yang produktif.

Sesuai dengan kodratnya guru itu adalah sebagai mahluk pribadi dan sekaligus mahluk sosial. Dalam hal ini, bagi guru terdapat dua kepentingan yaitu yang berhubungan dengan masalah pribadi dan kepentingan bersama untuk bermasyarakat. Kepentingan pribadi karena guru ingin memenuhi kebutuhan pribadi dan kepentingan bersama karena guru ini memenuhi kebutuhan bersama masyarakat

Guru secara pribadi maupun mahluk sosial ingin memenuhi kebutuhannya secara hirarki dari kebutuhankebutuhan fisik dan biologis sampai dengan kebutuhan aktualisasi diri (Maslow). Untuk memenuhi kebutuhan tersebut, guru tidak dapat berdiri sendiri. Ia harus bekerjasama dengan orang lain (Siswa, sesama guru, pimpinan dan masyarakat), oleh karena itu, guru secara pribadi dan secara bersama-sama selalu bergantung satu sama lain dan perlu mengadakan komunikasi dalam memenuhi kebutuhan. Agar tercipta komunikasi yang harmonis maka diperlukan suasana yang serasi, selaras dan seimbang.

Apabila dikaitkan dengan komunikasi, saling kerjasama ini merupakan tujuan dari komunikasi itu sendiri. Hal ini sesuai dengan sifat komunikasi yang bertujuan untuk mempengaruhi dan melakukan perubahan terhadap pendapat yang berbeda-beda dan memantapkan pendapat yang sama. ${ }^{3}$

Komunikasi memegang peranan penting dalam fungsi manajemen, yaitu sebagai bagian dari upaya untuk mengorganisasikan seluruh sumberdaya untuk mencapai tujuan organisasi. Peran penting komunikasi dalam hubungannya dengan pekerjaan ditunjukkan oleh banyaknya waktu yang dipergunakan untuk berkomunikasi. Menurut penelitian Robbin dalam hardin rata-rata setiap orang/karyawan melakukan komunikasi antara 16 sampai dengan 46 kali dalam satu jam. Manajer tingkat bawah melakukan komunikasi sebesar 29

${ }^{3}$ H.A.W. Widjaya, Ilmu Komunikasi, Pengantar Studi. (Jakarta: Rineka Cipta, 2000), h. 10 
sampai dengan 40 persen waktunnya, sedangkan manajer tingkat menengah melakukan komunikasi sebesar 29 sampai dengan 64 persen. ${ }^{4}$ Penelitian Maryono menyebutkan bahwa hanya 47,5 persen guru yang mampu berkomunikasi instruksional dalam bentuk kemampuan bertanya yang komunikatif dan effektif. ${ }^{5}$

Dari data di atas dapat ditarik kesimpulan bahwa kemampuan berkomunikasi sangat dibutuhkan oleh semua orang, tidak terkecuali guru dan siswa. Guru yang memiliki kemampuan berkomunikasi yang effektif, komunikatif akan sangat menunjang tugas dan tanggung jawabnya sebagai pengajar dan pendidik di sekolah dan perguruan tinggi

\section{Permasalahan}

1. Bagaimana motivasi mengajar guru di sekolah?

2. Faktor apa saja yang mempengaruhi motivasi mengajar guru?

3. Bagaimanakah meningkatkan motivasi belajar siswa melalui keterampilan komunikasi guru?

\section{Kajian Teori}

Motivasi berasal dari kara motif yang berarti keadaan dalam diri seseorang yang mendorong individu tersebut untuk melaksanakan aktifitias-aktifitas tertentu guna mencapai tujuan yang diinginkan (Suyobroto, 1984). Sedangkan menurut Winkel (1987) motif adalah daya penggerak dalam diri seseorang untuk melakukan aktifitas-aktifitas tertentu demi tercapainya suatu tujuan tertentu.

Motivasi adalah kekuatan tersembunyi di dalam diri seseorang yang mendorongnya untuk berkelakuan dan bertindak dengan cara yang khas. Kadang kekuatan itu berpangkal pada naluri, kadang pula berpangkal sesuatu keputusan rasional, tetapi lebih sering lagi hal itu merupakan perpaduan dari kedua proses tersebut. Motivasi mengarahkan seseorang untuk

${ }^{4}$ Carlette Jackson Hardin. Effective Classroom Management; model and strategies for today's classroom. (New Jersey: Pearson Education, Inc., 2004) h. 56

5 Maryono. "Tingkat Ketrampilan Bertanya Guru SLTP dalam komunikasi Pembelajaran." Jurnal Ilmu Pendidikan, Vol. 27 Nomor 1, Januari 2000, h. 3 
mengendalikan perbuatannya untuk menuju suatu tujuan yang dikehendaki. Motivasi adalah proses memunculkan aktifitas seseorang. Di sini motivasi mendorong seseorang untuk dapat melakukan sesuatu yang dikehendaki. Motivasi dapat memberikan arah dan intensitas tingkah laku yang tidak dikehendaki oleh seseorang atau tingkah laku yang tidak dikehendakinya.

Kesimpulan yang dapat diambil dari semua itu motivasi adalah keseluruhan/totalitas kekuatan yang tersembunyi dalam diri seseorang yang dapat menyebabkan seseorang tersebut mengarahkan tenaga energinya untuk melakukan sesuatu yang lebih dibanding yang lain dalam mencapai tujuan.

\section{Teori motivasi}

\section{a. Hirarki kebutuhan manusia menurut Abraham Maslow}

Jika seseorang sudah mempunyai suatu motivasi, maka ia dalam ketegangan dan siap mengerjakan hal-hal yang diperlukan sesuai dengan apa yang dikehendaki. Menurut Robbins motivasi menyangkut seperangkat kebutuhan yang oleh Maslow diklasifikasikan menurut kekuatan daya pendorong, yaitu:

1. Kebutuhan fisiologis (antara lain; haus, lapar, dan seks)

2. Kebutuhan keamanan (antara lain menyelamatkan jiwa, menjaga ketertiban)

3. Kebutuhan sosial (antara lain; kasih sayang, rasa memiliki, diterima baik, dan persahabatan)

4. Kebutuhan penghargaan (antara lain harga diri, status, pengakuan, dan perhatian)

5. Kebutuhan aktualisasi diri (antara lain: mengembangkan diri). ${ }^{6}$

Begitu tiap kebutuhan ini cukup banyak terpuaskan, maka kebutuhan lain akan menjadi dominan. Dari titik pandang motivasi, teori ini mengatakan bahwa meskipun tidak ada kebutuhan yang pernah terpenuhi secara lengkap, suatu kebutuhan yang dipuaskan secara cukup banyak tidak lagi memotivasi. Maslow memisahkan kebutuhan tersebut sebagai urutan tinggi dam urutan rendah. Kebutuhan fisiologis, kebutuhan akan rasa aman, dan kebutuhan sosial digambarkan

\footnotetext{
${ }^{6}$ Hardin, Effective Classroom, h. 75
} 
sebagai kebutuhan urutan rendah. Kebutuhan akan penghargaan dan aktualisasi diri sebagai kebutuhan urutan tinggi. Perbedaan antara kedua urutan itu, berdasarkan alasan bahwa kebutuhan urutan tinggi dipenuhi secara internal, sedangkan kebutuhan urutan rendah dipenuhi secara eksternal.

Dalam penerapan teori Maslow adalah bahwa untuk memotivasi seseorang kita perlu memahami terlebih dahulu kebutuhannya. Dengan mengetahui pada tingkat mana kebutuhan seseorang maka kita dapat memfokuskan pemenuhan kebutuhan-kebutuhan itu. Dalam pengajaran di kelas, pengajar (guru) dapat mengendalikan kebutuhan-kebutuhan siswanya.

\section{b. Motivasi instrinsik dan ekstrensik}

Berdasarkan fungsi dan perannya, motivasi dapat dibagai atas motivasi instrinsik dan motivasi ekstrensik. Kedua motivasi itu sangat penting artinya dalam kegiatan belajar siswa.

1. Motivasi instrinsik

Motivasi instrinsik mengacu pada faktor-faktor dari dalam, tersirat baik dalam tugas itu sendiri, maupun pada diri siswa. Motivasi instrinsik adalah motif-motif yang aktif atau berfungsinya tidak perlu dirangsang dari luar karena dalam diri seseorang sudah ada dorongan umtuk melakukan sesuatu. Contohnya; senang membaca. Adanya motivasi instrinsik atau motivasi internal ini menunjukkan bahwa siswa menyadari manfaat bagi dirinya dari kegiatan belajar yang sedang diikutinya karena sejalan dengan kebutuhannya. Keinginan untuk menambah pengetahuan dan untuk melacak merupakan faktor instrinsik pada semua orang.

\section{Motivasi Ekstrinsik}

Motivasi ekstrinsik mengacu kepada faktor-faktor dari luar, dan ditetapkan pada tugas atau pada siswa atau oleh orang lain. Motivasi ekstrensik adalah motif-motif yang aktif dan berfungsinya karena adanya rangsangan dari luar. Contohnya; seorang siswa ingin belajar karena penampilan gurunya yang menarik, motivasi ini muncul dikarenakan di dalam kegiatan belajar mengajar sering dijumpai bahwa motivasi instrinsik atau motivasi internal yang diharapkan tidak selamanya dimiliki oleh siswa, karana sangat tergantung pada diri seseorang. 
Hal ini bukan selanjutnya diartikan bahwa motivasi instrinsik lebih baik dari ekstrinsik. Dalam proses belajar mengajar motivasi instrinsik dan ektrinsik tetap penting, karena kemungkinan besar keadaan siswa yang dinamis dan berubahubah dan juga mungkin ada komponen lain dalam proses belajar mengajar yang kurang menarik bagi siswa sehingga diperlukan motivasi ekstrinsik.

Pada umumnya motivasi instrinsik berhubungan erat kaitannya dengan dua tingkat kebutuhan tingkat tinggi dari Maslow, sedangkan kebutuhan ekstrinsik behubugnan dengan kebutuhan tingkat rendah. Menurut Morisson dan Mclntyre dalam Ivor Davies (1986), kebanyakan guru lebih memikirkan motivasi ekstrinsik, hal yang nampak umpanya, diskusi tentang sangksi dan hukuman untuk meningkatkan mutu pembelajaran klasikal. Karena motivasi yang dibawa oleh motivasi instrinsik sering diabaikan, dan ada juga anggapan guru yang menggunakan motivasi instrinsik merupakan guru yang terlalu lunak .

\section{Motivasi Belajar}

Memperkuat motivasi belajar merupakan tugas dari seorang pengajar. Motivasi belajar adalah penerapan motivasi di bidang pendidikan, khususnya yang menyangkut proses belajar mengajar. Motivasi belajar adalah keseluruhan daya penggerak psikis di dalam diri siswa yang menimbulkan kegiatan belajar itu demi tercapainya suatu tujuan. Motivasi belajar merupakan faktor psikis yang bersifat non intelektual dan perannya yang khas adalah menumbuhkan gairah belajar, merasa senang dan semangat belajar.

Motivasi belajar memegang peranan penting dalam memberikan gairah semangat dan rasa senang dalam belajar sehingga siswa yang bermotivasi kuat memiliki energi yang banyak untuk kegiatan belajar. Adalah keliru apabila motivasi dianggap sebagai prasyarat mutlak untuk kegiatan belajar mengajar. Lebih baik motivasi itu dianggap sebagai kendaraan untuk memasuki sesuatu situasi belajar. Strategi yang paling baik adalah tanpa menghiraukan ada atau tidaknya motivasi akan tetapi memusatkan pada penyampaian materi dengan cara 
yang begitu rupa sehingga motivasi dapat dikembangkan dan diperkuat selama proses belajar mengajar.'

Beberapa ciri siswa yang memiliki motivasi belajar yang tinggi dapat dikenali selama proses belajar mengajar di kelas. Siswa yang memiliki motivasi belajar tinggi antara lain; (1) tertarik pada guru, artinya tidak membenci, tidak bersikap acuh tak acuh kepada guru, (2) tertarik pada mata pelajaran yang diajakan, (3) antusias tinggi serta mengendalikan perhatian dan energinya kepada guru, (4) ingin selalu tergabung dalam suatu kelompok kelas, (5) ingin identitas diri diakui orang lain, (6) tindakan, keingin, dan moralnya selalu dalam kontrol diri, (7) selalu mengingat pelajaran dan mempelajarinya kembali di rumah, dan (8) selalu terkontrol oleh lingkungannya. Ciri-ciri lain menurut Sardiman dalam Winskel (1987) adalah: (1) tekun dalam menghadapi tugas dan dapat bekerja secara terus menerus dalam waktu yang relatif lama, (2) ulet dalam menghadapi kesulitan, (3) menunjukkan minat dalam bermacam-macam dalam masalah belajar, (4) lebih senang bekerja mandiri dan tidak bergantung dengan teman lainnya, (5) cepat bosan pada tugas-tugas yang bersifat rutin (6) dapat mempertahankan pendapatnya, (7) tidak mudah melepaskan hal yang diyakini, dan (8) senang mencari dan memecahkan masalah.

\section{Fungsi motivasi dalam belajar}

Guru sesuai dengan tugasnya adalah sebagai fasilitator, motivator, sekaligus sebagai inspirator dalam di kelas (Winskel, 1987) kedudukan ini menunjukkan betapa penting peran guru dalam menumbuhkan motivasi belajar dalam diri siswa.

Sebagai fasilitator, guru harus dapat memberikan berbagai kemudahan, petunjuk, bantuan, dorongan, kepada siswa selama proses belajar-mengajar di dalam kelas, memberikan kemudahan, disini artinya sebagai guru jangan terlalu mempersulit kepentingan-kepentingan yang diperlukan siswa. Memberikan petunjuk termasuk petunjuk dalam belajar, mengarahkan bagaimana siswa dapat belajar dengan mudah dan sekaligus memberikan dorongan-forongan yang diperlukan siswa.

Sebagai motivator dalam proses belajar mengajar, guru harus dapat membangkitkan motivasi, hasrat, dan gairah belajar 
pada diri siswa. Jangan sampai guru hanya datang memberikan kuliah, mencatat dan kemudian mengakhirinya dengan memberikan ujian.

Sebagai inspirator, guru harus dapat memberikan semangat kepada tiap siswa, tanpa memandang taraf kemampuan intelektual atau tingkat motivasi belajarnya. Setiap siswa harus dapat dibuat senang bergarul dengan guru, baik di dalam maupun di luar kelas.

Dengan demikian dapat ditarik kesimpulan bahwa motivasi berfungsi sebagai pendorong dan penggerak manusia dalam berbuat, penentu arah perbuatan dan menyeleksi perbuatan manusia. Sebagai pendorong maka motivasi dapat menggerakdkan dan menumbuhkan keinginan siswa untuk belajar. Tanpa adanya suatu pendorong, maka sedikit keberhasilan siswa dalam belajar dan sangat minim prestasi yang dicapai oleh siswa. Sebagai penentu arah motivasi dapat menunjukkan arah perbuatan sehingga seorang siswa dalam belajar akan tahu apa yang harus dipelajarinya. Dengan adanya motivasi, siswa dapat belajar sesuai dengan yang diharapkan tanpa membuang energi yang melelahkan tetapi dapat berhasil dengan baik atau sempurna.

Motivasi sebagai penyeleksi perbuatan, yaitu menentukan perbuatan-perbuatan yang harus dikerjakan guna mencapai tujuan dengan menyisihkan perbuatan-perbuatan yang tidak bermanfaat dari tujuan tersebut. Demikian juga dengan siswa akan mengetahuinya mana yang harus dipelajarinya dan mana yang seharusnya tidak dilakukan.

\section{Peran dan Fungsi Komunikasi dalam Meningkatkan Motivasi Belajar}

Komunikasi didefinisikan sebagai proses penyampaian gagasan, harapan, dan pesan yang disampaikan melalui lambang tertentu, mengandung arti, dilakukan oleh penyampai pesan kepada penerima pesan. Komunikasi juga dapat diartikan sebagai proses dimana seseorang individu mengoperkan perangsang untuk mengubah tingkah laku individu-individu yang lain ${ }^{7}$. Komunikasi adalah proses kegiatan pengoperasian/

\footnotetext{
${ }^{7}$ H.A.W. Widjaya, Ilmu Komunikasi, h. 20
} 
penyampaian informasi yang mengandung arti dari satu pihak ke pihak yang lain. ${ }^{8}$

Dari definisi di atas dapat disimpulkan bahwa dalam proses komunikasi setidak-tidaknya ada 7 unsur yaitu; komunikator, pesan, saluran, model komunikasi, efek, dan faktor-faktor yang diperhatikan dalam proses komunikasi.

Komunikator adalah setiap orang atau kelompok yang menyampaikan pesan. Pesan adalah keseluruhan isi yang disampaikan oleh komunikator. Saluran adalah media yang digunakan untuk menyampaikan pesan. Model komunikasi adalah sasaran yang digunakan dalam berkomunikasi. Efek adalah hasil akhir dari suatu komunikasi, yaitu sikap dan tingkah orang lain terhadap proses komunikasi.

Proses pembelajaran pada hakikatnya adalah proses komunikasi, yaitu penyampaian pesan, dari berbagai sumber pesan melalui media tertentu ke penerima pesan/siswa (Tjokronegoro, 2000). Proses pembelajaran melalui komunikasi merupakan kegiatan untuk mengembangkan seluruh kepribadian siswa, yang mencakup kawasan kognitif, afektif dan psikomotor.

Guru sebagai pengajar sekaligus pendidik di perguruan tinggi menjalankan fungsi dan tugasnya melalui proses komunikasi, yaitu sebagai komunikator sekaligus sumber pengetahuan. Dalam proses pembelajaran terdapat suatu proses berkomunikasi antara guru dengan guru dan guru dengan siswa. Proses komunikasi guru dengan siswa terjadi kebanyakan di dalam kelas di mana hampri $100 \%$ dalam proses pembelajaran juga merupakan proses berkomunikasi. Guru sebagai komunikator dan siswa sebagai komunikan merupakan dwitunggal dalam pembelajaran di kelas. Guru berfungsi untuk menyampaikan pesan berupa pengetahuan, keterampilan dan seni, sedangkan siswa sebagai komunikan menerima pesan berupa ilmu pengetahuan dari guru. Oleh karena itu diperlukan strategi yang tepat untuk meyampaikan pesan yag bertujuan untuk merubah tingkah laku siswa sebagai akibat dari proses

${ }^{8}$ Lembaga Administrasi Negara. 1995. Komunikasi; Bahan Materi Pendidikan dan Pelatihan prajabatan Pegawai Negeri Sipil golongan III. Jakarta: LAN 
belajar dan rekonstruksi pengetahuan, keterampilan dan afektifnya sehingga dapat mengaplikasikannya ke dalam kehidupan sehari-hari.

Goleman (1999) menyatakan bahwa menjadi komunikator yang baik mempersyaratkan diri untuk dapat mengendalikan diri (kecerdasan untuk mengendalikan emosi diri sendiri) tetap "berkepala dingin" yaitu mampu menguasai diri sendiri, bersikap tenang, terkendali dan sabar dalam berkomunikasi. Dari pendapat Goleman di atas dapat disimpulkan bahwa untuk menjalin komunikasi yang efektif antara guru dengan siswa perlu dibangun kesetaraan emosi/perasaan. Guru dituntut untuk, dapat membaca, mengendalikan, dan mengelola emosi siswa sehingga terjadi komunikasi timbal balik yang effektif. Di samping itu, guru diharapkan menguasai materi yang akan diajarkan serta memiliki keterampilan berkomunikasi dalam pengelolaan kelas.

Dalam proses belajar-mengajar yang effektik diperlukan interaksi tingkat tinggi berupa komunikasi baik verbal maupun non-verbal dalam suasana yang saling mempercayai antara guru dan siswa (Cangelosi, 1993). Joni menyatakan bahwa keefektifan pembelajaran memerlukan kompetensi dan keterampilan antara lain penguasaan bahan ajar dan keterampilan berkomunikasi (Maryono, 2000).

Orang yang terampil dalam berkomunikasi memiliki ciri; (1) efektif dalam memberi dan menerima, menyertakan isyaratisyarat emosi dalam pesan-pesan mereka, (2) menghadapi masalah-masalah sulit tanpa penundaan, (3) mendengarkan dengan baik, berusaha saling memahami dan bersedia berbagi informasi, (4) menggalakkan komunikasi terbuka dan tetap bersedia menerima kabar buruk maupun baik (Goleman, 1999). Untuk menjadi guru yang sukses dalam pembelajaran dibutuhkan kemampuan dan keterampilan berkomunikasi yang effektif sehingga mampu merubah perilaku siswa sebagai akibat dari proses pembelajaran. Untuk mengubak perilaku siswa diperlukan juga kemampuan dan seni untuk mempengaruhi. Oleh karena itu perlu dibangun suatu kepercayaan antara guru dan siswa. Hal ini akan mempermudah guru untuk menemukan ikatan atau kesamaan yang dapat dijadikan dasar dalam tindakan persuasif. Guru yang memiliki kecakapan ini menurut Goleman 
dikategorikan; (1) terampil dalam persuasi, (2) mampu menyesuaikan diri dalam presentasi untuk menarik perhatian siswa, (3) membangun konsensus dan dukungan masyarakat, dan (4) mampu memadukan dan menyelaraskan peristiwa aktual untuk menghasilkan proses pembelajaran yang effektif.

Guru adalah sebagai komunikator dalam menyampaikan pesan yang dikemas dalam bentuk informasi perlu memperhatikan pertimbangan-pertimbangan, yaitu: (1) Situasi, keadaan yang dikehendaki, (2) Sasaran, mengenai tujuan yang ingin dicapai, (3) apa, mengenai pesan dan informasi, (4) bagaimana, tentang cara penyampaian, (5) dengan apa, tentang alat-alat dalam penyampaian, (6) dimana, tentang tempat proses komunikasi berlangsung. Pertimbangan ini, dimaksudkan agar komunikator dapat mempersiapkan pesan atau informasi sebaikbaiknya dan menguasai informasi tersebut. Pengalaman membuktikan bahwa guru sebagai komunikator yang menyampaikan dengan gaya bahasa yang benar adalah sangat effektif. Hal ini akan memperlancar proses komunikasi dan akan mencipatakan komunikasi yang harmonis.

\section{Komunikasi dalam proses pembelajaran}

Kemampuan berkomunikasi dalam proses pembelajaran dimulai adanya asesmen kebutuhan terhadap kemampuan siswa. Vygotsky menyarankan perlunya mengenali dan mengidentifikasi terhadap batas-batas kemampuan siswa dalam menyerap pembelajaran dengan apa yang disebut dengan the zone of proximal development (Moll, 1994). Goleman (1999) menyatakan bahwa seseorang dikatakan memiliki kecerdasan emosional yang tinggi apabila dia mampu mengendalikan diri, mampu mengelola emosinya dan emosi orang lain serta mampu berempati. Sedangkan menurut Gardner (1995) mempersyaratkan kecerdasan bahasa sebagai salah satu kecerdasa intelektual yang diperlukan dalam mengolah kata dan kecerdasa kinestetik yang diwujudkan dalam gerak-gerik tubuh, isyarat dan ekspresi wajah.

Untuk menunjang kemampuan berkomunikasi di kelas, Usman (2000) menyarankan perlunya dikuasai 8 keterampilan mengajar yang dijabarkan sebagai berikut; (1) keterampilan bertanya, (2) keterampilan memberikan penguatan, 
keterampilan mengadakan variasi, (4) keterampilan menjelaskan, (5) keterampilan membuka dan menutup pelajaran, (6) keterampilan membimbing kelompok diskusi, keterampilan mengelola kelas, dan (8) keterampilan mengajar perseoarangan. Keterampilan bertanya meliputi komponen; (1) pengungkapan pertanyaan secara jelas dam singkat, (2) pemberian acuan, (3) pemindahan giliran, (4) penyebaran ke seluruh kelas, (5) pemberian waktu berfikir, dan (7) pengungkapan tuntunan, yaitu pengungkapan pertanyaan dengan cara lain.

Keterampilan memberikan penguatan meliputi 2 komponen, yaitu penguatan yang bersifat vebal dan non verbal. Penguatan verbal misalnya dengan kata-kata; bagus, benar, dan tepat. Penguatan non verbal misalnya dengan gerak-gerik, mimik, mendekati dan sentuhan.

Keterampilan mengadakan variasi meliputi komponen; (1) suara; nada suara, kecedpatan dan volume suara, (2) mimik dan gerak-gerik badan untuk memperjelas, (3) memberikan waktu hening dalam pembicaraan, (4) kontak pandang dengan siswa, (5) perubahan posisi gerak, dan (7) variasi dalam penggunaan media dan sumber belajar.

Keterampilan menjelaskan meliputi komponen; (1) kejelasan, yaitu menggunakan kalimat yang dipahami siswa, (2) penggunaan ilustrasi yang tepat, yaitu contoh sesuai dengan kemampuan siswa, (3) pengorganisasian materi yaitu dengan memberikan ihtisar butir yang penting, dan (4) balikan yaitu mengajukan pertanyaan yang digunakan untuk mengetahui tingkat pemahaman siswa.

Keterampilan membuka dan menutup pelajaran meliputi komponen; (1) menarik perhatian siswa, (2) menimbulkan motivasi untuk belajar, (3) memberi acuan, (4) membuat kaitan, (5) meninjau kembali/merangkum materi, dan (6) mengevaluasi.

Untuk mewujudkan berkomunikasi yang efektif dalam pengelolaan kelas, seyogyanya guru memenuhi kriteria sebagai berikut; (1) bersemangat, (3) harus bersifat kritis, (4) harus memiliki sifat dan tindakan terpuji, (5) harus memelihara proses komunikasi yang sedang berlangsung, dan (6) harus menyadari kebiasaan ayng berlebihan. 
Oleh karena itu, cara dan gaya bahasa harus dikemas lebih menarik minat siswa untuk selalu memperhatikan di kelas, maka seorang guru sedapat mungkin untuk; (1) berbicara perlahan, tidak terlalu keras atau terlalu perlahan, (2) berbicara bersemangat, suara yang bersemangat akan mempengaruhi khalayak sehingga tidak mudah jemu dan menjemukan, (3) berbicara dengan tekanan tertentu; (a) ada selingan antara suara yang tinggi dan rendah, (b) ada tekanan informasi atau pesan yang penting yang harus mendapatkan perhatian ekstra, (c) menggunakan efek pembicaraan tertentu (berhenti sebentar). ${ }^{9}$

\section{Faktor-faktor Yang Mempengaruhi Komunikasi Pembelajaran di Kelas}

Ada beberapa faktor yang dapat mempengaruhi kelancaran proses komunikasi di kelas. Faktor-faktor tersebut dapat digolongkan sebagai hambatan terhadap komunikasi yang effektif. Menurut Stoner faktor penghambat tersebut adalah perbedaan persepsi, perbedaan bahasa, reaksi emosional, komunikasi yang tidak konsisten serta ketidak percayaan.

\section{Persepsi}

Perbedaan antar individu yang satu dengan yang lainnya merupakan hal yang manusiawi. Perbedaan itu disebabkan oleh latar belakang etnik, pendidikan, pengetahuan, pengalaman dan sebagainya. Hal ini harus dipelajari guru mengenai latar belakang dan budaya siswanya.

\section{Perbedaan Bahasa}

Perbedaan bahasa sering dikaitkan dengan perbedaan persepsi individu agar pesan dapat dikomunikasikan secara tepat. Kata-kata yang disampaikan harus memiliki kesamaan arti dengan pengirim dan pesan dalam hal ini guru dan siswa. Tidak jarang guru menggunakan kata-kata ke-asing-asing-an sehingga penjelasan guru sulit diterima oleh siswa. Untuk mengatasi hal ini apabila terpaksan menggunakan kata-kata asing perlu dijelaskan dulu agar tidak mengganggu proses penyampaian pesan/informasi atau pengetahuan.

\footnotetext{
${ }^{9}$ H.A.W. Widjaya, Ilmu Komunikasi, h. 21
} 


\section{Reaksi Emosional}

Reaksi emosional seperti marah, gembira, benci, cemburu, cinta, takut dan gelisah yang berlebihan akan mempengaruhi bagaimana memahami pesan yang diterima. Suasana yang mencekam membuat siswa sulit untuk menerima pesan yang disampaikan oleh gurunya. Pendekatan terbaik adalah dengan mempelajari emosi sebagai bagian dari proses komunikasi itu sendiri. Goleman menyarankan agar ditumbuh kembangkan empati antara guru dengan siswanya. ${ }^{10}$

\section{Komunikasi Yang Tidak Konsisten Antara Verbal Dan Non Verbal}

Komunikasi yang baik adalah adanya kesesuaian antara ungkapan verbal dan non verbal. Dalam proses pembelajaran kesesuaian ini merupakan keharusan. Bila sang guru mengucapkan selamat padi sambil memandang atap tentu saja reaksi emosional siswa akan lain dan bahkan tanpa reaksi psikologis sama sekali. Oleh karena itu perlu perhatian yang terfokus dalam berkomunikasi merupakan bagian dalam proses pembelajaran itu sendiri.

\section{Ketidak Percayaan}

Kredibilitas sebuah pesan sebagian besar ditentukan oleh kredibilitas pengirimnya dan kredibilitas pengetahuan yang disampaikan guru bergantung pada kreditbilitas guru itu sendiri. Biasanya kredibilitas guru akan tinggi apabila ia dianggap siswa sebagai guru yang berpengetahuan dan berwawasan luas, akrab dengan sesama, dapat dipercaya, tulus hati dan memperhatikan kemajuan belajar siswa. Kredibilitas guru yang bergelar doktor akan berbeda dengan mereka yang bergelar S-1, tentu saja siswa pada umumnya menganggap dan lebih mempercayai guru yang bergelar doktor dari strata satu pendidikan

${ }^{10}$ B. Sukarno. "Kontribusi Motivasi dan Prestasi Belajar terhadap Kemampuan Mengajar.” Jurnal Ilmu Pendidikan, Nomor 3, Mei 1999 


\section{Usaha-usaha yang dapat Dilakukan Untuk Meningkatkan Motivasi Belajar Siswa melalui Kemampuan Berkomunikasi Guru}

Untuk mengembangkan kemampuan berkomunikasi guru dalam proses pembelajaran dan hubungan interpersonal antar sesama guru diperlukan analisis mendalam terhadap masalah-masalah apa saja yang dihadapi guru dalam berkomunikasi. Dalam hal ini, perlu diadakan pemahaman dan fungsi komunikasi tersebut sebagai penunjang dan alat mencapai tujuan. Hal-hal yang dapat dilakukan untuk meningkatkan kemampuan berkomunikasi adalah:

1. Melakukan introspeksi pada diri sendiri apakah yang selama ini dikerjakan dalam berkomunikasi sudah baik atau belum. Evaluasi diri terhadap kemampuan guru dapat dilakukan melalui sosiometri dan survey kepada siswa terhadap kemampuan guru dalam berkomunikasi. Apabila kemampuan berkomunikasi guru baik, akan berdampak pada motivasi belajar siswa. ${ }^{11}$ Hal ini dapat dilakukan oleh kepala sekolah/pimpinan atau guru itu sendiri melalui evaluasi pembelajaran akhir semester untuk memperoleh balikan dari siswa.

2. Mengadakan pelatihan berkomunikasi yang efektif dalam proses pembelajaran yang berkaitan dengan peningkatan motivasi siswa dalam pembelajaran. Pelatihan tersebut dapat dilakukan dengan menggunakan kecerdasan intelektual bahasa dan kecerdasan kinestetik. Pelatihan tersebut diharapkan dapat meningkatkan kemampuan dasar mengajar guru melalui simulasi, praktek lapangan dan penelitian action research

3. Mensosialisasikan terhadap pentingnya menerima kritik dan perubahan serta inovasi sebagai upaya untuk meningkatkan kemampuan mengajar melalui berkomunikasi effektif, yaitu dengan mempengaruhi guru agar selalu terbuka dan

11 Rita Norce Taroreh, 2004. Hubungan antara persepsi siswa terhadap cara berkomunikasi verbal dan non-verbal guru dengan motivasi belajar siswa jurusan manajemen di Fakultas Ekonomi Universitas Sam Ratulangi Manado. Universitas Negeri Malang: Tesis. Tidak dipublikasikan h. 5 
berpandangan positif untuk mengembangkan kariernya sebagai guru di perguruan tinggi.

4. Meningkatkan dan menggalakkan supervisi pengajaran dengan fokus kemampuan berkomunikasi guru. Kegiatan ini dapat dilakukan oleh kepala sekolah, pembantu kepala sekolah, dan guru senior sebagai supervisor. Hasil dari supervisi ini didiskusikan secara terbuka antara supervisor dengan guru yang bersangkutan

5. Mensosialisasikan aplikasi kecerdasan emosional sebagai seni beregaul, seni berkomunikasi, dan seni untuk mempengaruhi siswa dalam komunikasi pembelajaran di kelas maupun di luar kelas, sehingga proses pembelajaran dan komunikasi antara guru dan siswa berjalan dengan lancar dengan memahami dan berempati terhadap siswa.

\section{Daftar Pustaka}

Beare, Hedley etc. Creating an excellent School. New York: Capman and Hall inc. 1989.

Emmer, ET, Evertson, CM. Classroom Management for Secondary Teachers. New Jersey: Englewood Cliffs, 1984.

Hardin, Carlette Jackson. Effective Classroom Management; model and strategies for today's classroom. New Jersey: Pearson Education, Inc. 2004.

Joyce, Erna, Models of Teaching. New York: Prentice Hall Inc, 1982.

Levin. James. Principles of Classroom Management: A professional Decision-Making Model. Boston: Allyn and Bacon, 1996.

Cangelosi, J.S. Classroom Management Strategies: Gaining and Maintaining Students' Cooperation. London \& New York : Longman Group Ltd, 1993.

Lembaga Administrasi Negara. Komunikasi; Bahan Materi Pendidikan dan Pelatihan prajabatan Pegawai Negeri Sipil golongan III. Jakarta: LAN, 1995. 
Maryono. "Tingkat Keterampilan Bertanya Guru SLTP dalam komunikasi Pembelajaran." Jurnal Ilmu Pendidikan, tahun 27 Nomor 1, Januari 2000.

Mustiningsih. Komunikasi sekolah dengan Masyarakat di Sekolah Dasar; Masalah dan upaya pemecahannya. Jurnal Ilmu Pendidikan, tahun 22 Nomor khusus, Oktober 2005.

Rakhmat, Jalaludin. Psikologi Komunikasi. Jakarta: PT Remaja Rosdakarya, 2001.

Sukarno. B. Kontribusi Motivasi dan Prestasi Belajar terhadap Kemampuan Mengajar. Jurnal Ilmu Pendidikan, Nomor 3, Mei 1999.

Taroreh, Rita Norce. Hubungan Antara Persepsi Siswa Terhadap Cara Berkomunikasi Verbal Dan Non-Verbal Guru Dengan Motivasi Belajar Siswa Jurusan Manajemen Di Fakultas Ekonomi Universitas Sam Ratulangi Manado. Universitas Negeri Malang: Tesis. Tidak dipublikasikan, 2004.

Tilaar, H.A.R., Manajemen Pendidikan Nasional: Kajian Pendidikan Masa Depan, Bandung: Remaja Rosdakarya, 1998.

Tjokronegoro, Arjatmo. Mutu dan Professionalisme Guru dalam perspektif abad 21. Makalah disampaikan pada seminar nasional reposisi dan Reorientasi Pendidikan Tinggi menghadapi tantangan abad 21 di Semarang, tanggal 15 Juli 2000.

Usman, M.U., Menjadi Guru Professional. Jakarta: Remadja Rosdakarya, 2000.

Wiryohandoyo, Soedarno. Komunikasi Dosen-Mahasiswa dalam Kegiatan Akademik. Jurnal Ilmu Pendidikan, Nomor 3, Agustus 1999.

Widjaya, H.A.W. Ilmu Komunikasi, Pengantar Studi. Jakarta: Rineka Cipta, 2000. 